\title{
Neglected Role of User in Prominent IS Models and Framework
}

\author{
HosseinMonem \\ Faculty of Computing, \\ UTM, Malaysia
}

\author{
AbRazakCheHussin \\ Faculty of Computing, \\ UTM, Malaysia
}

\author{
Roxana Sharifian \\ School of management \& \\ Medical Information \\ Science, Shiraz University \\ of Medical Sciences, \\ Shiraz, Iran
}

\author{
MohammadAfrasiabi \\ Faculty of Mechanical \\ Engineering, UTM, \\ Malaysia
}

\begin{abstract}
In modern world, organizations implement the Information System (IS) solution to achieve a range of business benefits and manage the huge amount of produced information. In spite of the importance of information system solution for organizations, the success rates of such IS implementation remain quite low. Although many investigations have been done on IS models and framework, the role of user in IS success measurement is neglected, especially in mandatory system usage. Therefore, more effective theoretical model of IS success measurement is needed for an organization's managers to get better understanding of the role of user to decrease existing failure risks. In order to clarify the aforementioned problem, this research reviewed prominent IS models, framework, and theory and compared them to each other. In this study, an exploratory phase followed to identify existing gap in IS models, framework, and theory.
\end{abstract}

\section{General Terms}

Information System, Success Measurement Model, IS Benefits, System Quality, Service Quality, Information Quality, User Quality, Usage Quality, and Satisfaction Quality.

\section{Keywords}

Role of User, IS Success Measurement Model, DeLone and McLean IS Success Model, IS-impact Measurement Model, ES Benefits Framework, UTAUT.

\section{INTRODUCTION}

In modern world, due to rapid increase in the amount of medical information, and in order to achieve a range of business benefits, Information System (IS) software solutions implement. This approach pushed organizations to the critical issues. These crucial issues are "how organization should be utilized to manage huge amount of produced information" and then enhance the quality of the delivered customer services[1] and accordingly, to ensure that their system are effective or "successful" [2].

However, the users' roles in information technology acceptance researches were investigated [3-5], observation showed that organizations tend to neglect the roles of users during measuring the success of an information system [2] and then users' characteristics and capabilities roles in success of the IS models has been ignored.

Furthermore, many disappointed results were shown by many business reports, academic experts and research groups which IT implementation failure rate is quite high [6-10], while researchers investigated IT implementation success factors $[6$, $11,12]$. In order to increase success rate of implementing IS in organizations, the neglected role of user should be cleared in IS success models and framework that have both academic and practical implications. This paper reports initial findings of related literature review by introducing an existing gap on the IS models.

The remaining parts of the paper are organized in the following manner. The paper begins with summarizing the well-validated IS success models, framework, and theory and then literatures are presented. Next, existing gap was cleared by compare the IS models, framework, and theory. Finally, discussion and conclusion are presented.

\section{IMPORTANT MODELS AND FRAMEWORKS OF IS SUCCESS}

The main point of IS success measurement model is the role of user in measuring success of IS in an organization. The role of user is included of user participation, user involvement, and user engagement that influence information system success."User participation" is defined as the observable behavior of information system users in the information system development process, while "the user involvement" point to basic attitude or psychological state of user. "User engagement" refers to the set of user behavior and attitude toward information systems [13].

During last two decades, the success of information systems has been evaluated strongly by different researchers [14-18]. In order to explain what makes information system successful, some IS models have been introduced by previous researchers. The Theory of Reasoned Action (TRA) andTheory of Planned Behavior (TPB) [19] were used by Davis's [3] in order to explain the reasons of the better acceptance technology which is different from persons to person. However, acceptance has not same mean as success, information system acceptance by users is necessary and preliminary precondition to achieve success [20].

The three most salient IS models [21] which are discussed briefly here, are: the (1) DeLone and McLean models, (2) Enterprise System (ES) benefits framework, and (3) the IS-impact measurement model. Although, the three aforementioned IS models were considered as crucial theoretical foundation for this research, there is no statistically validated IS success measurement model to clarify the role ofuser.

The first and most important IS model which has been widely used and cited, is DeLone and McLean IS success model [14, 18]. In this model not only the causal relationship between the six dimensions consist of systems quality, information quality, intention to use / use, user satisfaction, and net benefits (individual and organizational impact) were provided, but also prominent observe items for each construct from previous studies were summarized [21]. The mentioned models (original and updated) have been criticized, applied, validated, 
and modified by many researchers $[15,16,22-24]$ since it's incepted.

The second one is ES benefit framework. This model was proposed by Shang and Seddon[25]. The ES framework classified benefits of enterprise resource planning system. Five dimensions of ES consisted of operational benefits, managerial benefits, strategic benefits, IT infrastructure benefits, and organizational benefits.

The third one is IS-impact measurement model which was derived in the context of enterprise systems by Gable et al. (2008), and generalized to the IS domain. Since its inception, IS-impact was considered as an assessment tool to indicate success of an information system, thus it has been accepted and cited model among researchers. Individual Impact, Organization Impact, System Quality, and Information Quality with 37 observed measures formed the IS-Impact model. The IS-Impact model not only was accurately treated model's dimensions but also it was "the sub-constructs as a formative index rather than implying causality amongst the dimensions"[21].

Due to the perceived lack of measures and dimension to adequately indicate the level of user's role (characteristics, capability, etc.) in success of IS applications, assessment of information systems benefits have never been done entirely appropriate by the three aforementioned models and framework. However, study approaches, measures and dimensions of the DeLone and McLean model have been adopted much through studies. Insights and knowledge on how a model can be modified and extended into other information system domains have been provided by the D\&M success model and the relevant previous literatures. The following sections are discussed each one of the aforementioned model and frameworks in detail.

\subsection{The DeLone and McLean IS success model}

Due to the multi-dimensional, interdependent and complex nature of IS success, early attempts in order to define information system in the world were not successful [20]. To cover this gap, DeLone and McLean (D\&M) in 1992 introduced taxonomy of information system success by reviewing all related researches between 1981 and 1987. Six IS construct consist of system quality, information quality, use, user satisfaction, individual impact, and organizational impact were identified. However, these six variables were independent variables and were dependent success measures [14]. Fig 1 illustrated the original D\&M information system success model.

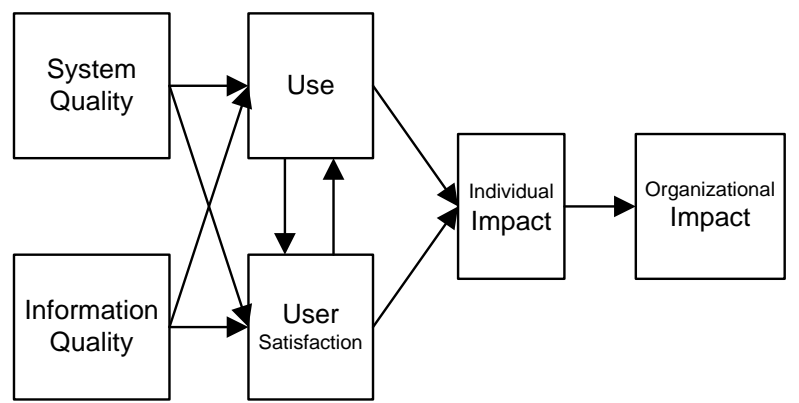

Fig 1: DeLone and McLean Original IS success model [14]

After announcement for further development and validation by Delone and McLean, proposing model modifications were begun by IS researcher in the world. Pitt et al [26] introduced service quality as a new dimension of information system effectiveness and after examination of content validity, reliability, convergent validity, nomological validity, and discriminant validity, they concluded that SERVQUAL is a suitable instrument for measure of information system service quality.

One of the most important studies was conducted by Seddon and Kiew in year 1996. They only studied on system quality, information quality, use, and user satisfaction and did not evaluate individual and organizational impact of the model. Due to their claim that "conjectured that the underlying success construct that researchers have been trying to tap is Usefulness, not Use" [27], Seddon and Kiew just modified the construct of use in their evaluation. As same as perceived usefulness in Technology Acceptance Model (TAM) by Davis [3], usefulness had same concept for Seddon and Kiew. They believed that in the voluntary usage of the system, use is a suitable manifest; however in the mandatory usage of the system, use is not a good measure as usefulness for IS success. After seven years, D\&M in 2003 answered to the Seddon and Kiew criticize and retained use and claimed that "in mandatory systems, there can still be considerable variability of use" [20]. Moreover, Seddon proposed a modification on the model and called for revise or extend the model. Modifications have been done by different researchers and have been evaluated the success of modified model on specific information system applications such as e-commerce [28-30] and knowledge management [31-33] and some of researchers proposed general recommendations to the model [34]

Other criticisms that influenced the original model were the effect of information system on the level other than the level of individual and organizational impact. Seddon et al. [35] and Myers et al. [16] claimed that IS success affects workgroups, industries, and even societies. Thus, individual impact and organizational impact was replaced with net benefits.

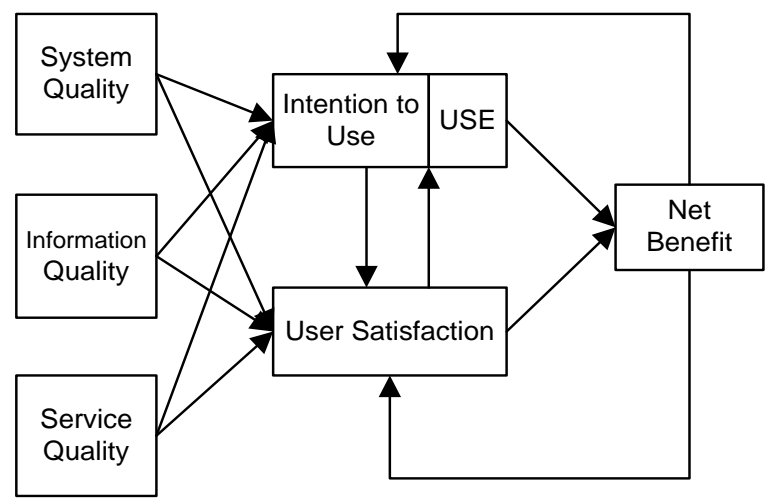

Fig 2: DeLone and McLean Updated IS success model [18

DeLone and McLean followed up the criticisms, modifications and extensions on the model throughout the ten years after introducing the original model. They reviewed empirical studies that were performed at that time. Therefore, they updated the original model and introduced revised model at the 2002 and 2003. This revision allowed researchers consider and apply the updated model to all levels of analysis. Fig 2 depicts the updated DeLone and McLean IS success model[20].

Researchers in empirical validated study found that the D\&M IS model is a useful framework for organizing IS success measurements. This is why the model widely were used for understanding and measuring the dimensions of IS success by IS researchers. Moreover, each of mentioned constructs in the 
updated D\&M IS success model was consistent with other success variables [20].

Researchers in empirical validated study found that the D\&M IS model is a useful framework for organizing IS success measurements. This is why the model widely were used for understanding and measuring the dimensions of IS success by IS researchers. Moreover, each of mentioned constructs in the updated D\&M IS success model was consistent with other success variables [20].

\subsection{Enterprise System Benefit Framework}

The enterprise system (ES) benefit framework was proposed by Shang and Seddon (2002) in order to summarize benefits in the years after enterprise system [25]. The ES framework classified benefits of enterprise resource planning system. Five dimensions of ES consisted of operational benefits, managerial benefits, strategic benefits, IT infrastructure benefits, and organizational benefits which have measured by 25 lower levels observe variables. Moreover, ES framework has used as a survey instrument [21].

Enterprise system also mentions to integrated enterprise system software solution. Enterprise systems software includes supply chain management, enterprise resource planning, customer relationship management, e-Procurement software, and Product Life Cycle Management (PLM) [25]. ES benefits framework has presented five different benefits. The benefit types are mentioned below briefly in the examination of the sub-dimensions of each of the five main benefit dimensions, while Fig 3 illustrated ES benefit framework.

- Operational benefits (dimension 1). Daily activities that involve acquiring and consuming resources have been being process by operational activities.

- Managerial benefits (dimension 2). Management activities usually rely on summarized information or exception reports and consist of monitoring of operations, control and allocating the firm's resources, and supporting of business strategic decisions.

- Strategic benefits (dimension 3). Strategic activities consist of long term planning, such as marketing competition, customer retention, business merging and acquisition, capital sourcing, and product planning.

- IT infrastructure benefits (dimension 4). IT infrastructure has defined as "sharable and reusable IT resources that provide a foundation for present and future business applications.

- Organizational benefits (dimension 5). ES benefits of organization in terms of focus, cohesion, learning and execution of its chosen strategies, increase the benefits of organization dimension.

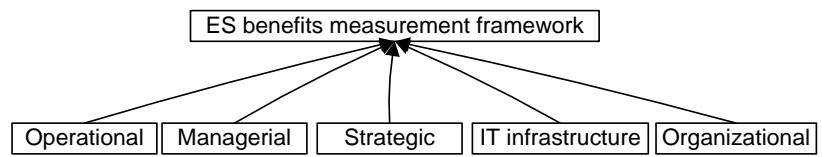

Fig 3: Illustration of the enterprise system benefits framework

\subsection{IS-Impact Measurement Model}

The IS-impact model consist of two halves that are depicted in Fig 4; first half is impact half which is "represented by the individual-impact and organizational-impact dimensions", and the second half is quality half which "is represented by the system-quality and information-quality dimensions", Gable et al. (2008) defined two halves as follow:
- Individual-impact is "a degree of the extent to which (the IS) has impacted the capabilities and effectiveness, on behalf of the organization, of key-users".

- Organizational-Impact is "a measure of the extent to which (the IS) has promoted improvement in organizational results and capabilities"

- Information-Quality is "a measure of the quality of (the IS) outputs: namely, the quality of the information the system produces in reports and on-screen"

- System-Quality is "a measure of the performance of (the IS) from a technical and design perspective".

Gable et al. [15] claimed that the model does not purport (is not concerned with) any causality among the dimensions; somewhat, similar to analytic theory [36], the constructs are postulated to be formative dimensions of the multidimensional concept of a-Impact in which the dimensions have a causal association with the overarching measure IS-Impact. The IS-Impact model adopts constructs which have represented by DeLone and McLean as causally or related process, however engagements them for an altered purpose. Aforementioned Impacts (individual and organizational) are explicitly and intentionally evaluated at the same time as quality (system and information); as same as previous model, up to a point in time and had not been mediated by user satisfaction or intention to use and use.

Therefore, Gable et al.(2008) proposed that "the validated constructs and measures of the IS-Impact model can be used in combination as dimensions of a measurement model for the purpose of evaluating overall IS-Impact". Otherwise, these same variables and their related, validated measures may be used in a nomological net to test causality. However, close and more attention should be paid to the timing of measurement and the consequent direction of the relations. In addition, Gable et al. (2008) gave an example of how the same constructs and variables can be employed for divers' purposes.A-priori model of the IS-impact measurement model measured the impact of IS on the individual impact by four measures, the organizational impact by eight measures, the system quality by fifteen measures, and the information quality by ten measures.

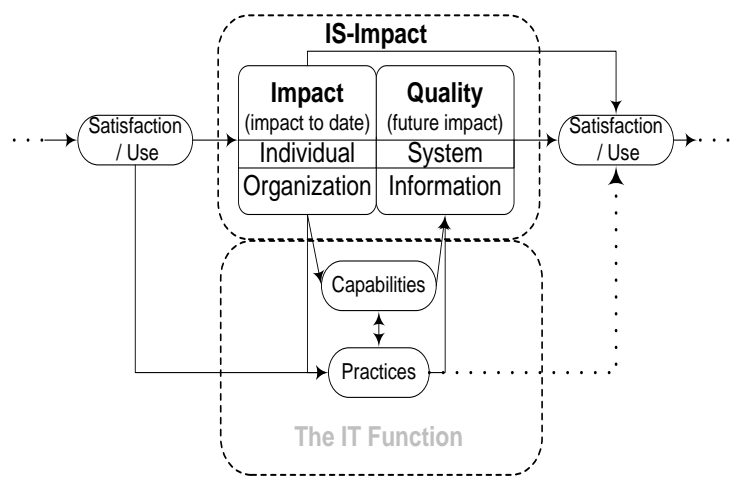

Fig 4: The IS-impact measurement model [15]

\section{UNIFIED THEORY OFACCEPTANCE AND USE OF TECHNOLOGY (UTAUT)}

UTAUT is an extended and concluded of theories that listed in Table 1. Subjective norm, human behavior, and user's attitude were discussed by Fishbein and Ajzen [19] in the theory of reasoned action. TRA was extended by the construct of behavioral control $[37,38]$. Davis $[3,39]$ used the TRA in terms of IT acceptance and The Technology Acceptance 
Model (TAM) by Davis [39] and Davis [3] applies the TRA in the context of IT acceptance and claimed that usage behavior is specified by perceived ease of use and perceived usefulness.

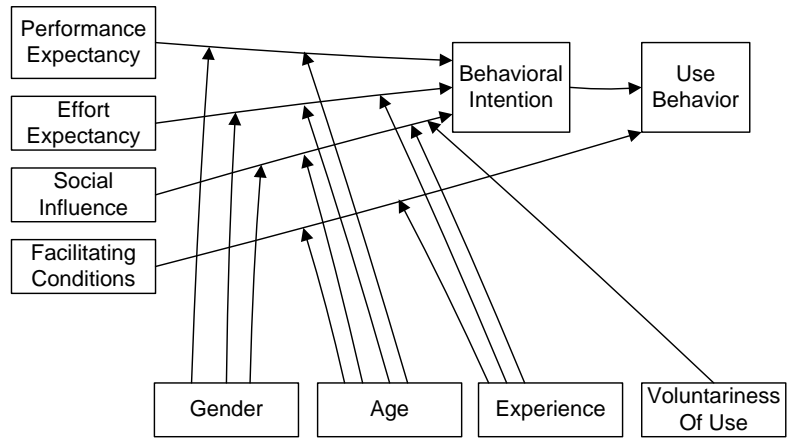

Fig 5: Unified Theory of Acceptance and Use of Technology [4]

Finally, Venkatesh and Morrisand the others (2003) extended TAM to UTAUT. In the UTAUT, behavior intention and use behavior affected by performance expectancy, effort expectancy, social influence, and facilitating condition. The aforementioned constructs are moderated by gender, age, experience and voluntariness of use. Fig 5 depicts the UTAUT.

Table 1: Summary of models and theories of individual acceptance

\begin{tabular}{|c|c|}
\hline \\
\hline Theory - model & Construct \\
\hline \multirow{2}{*}{$\begin{array}{c}\text { Theory of Reasoned } \\
\text { Action (TRA) }\end{array}$} & Attitude towards act or Behavior \\
\hline & Subjective Norm \\
\hline \multirow{5}{*}{$\begin{array}{c}\text { Technology } \\
\text { Acceptance Model }\end{array}$} & perceived usefulness \\
\hline & perceived ease of use \\
\hline & subjective norm \\
\hline & Experience \\
\hline & Voluntariness \\
\hline \multirow{2}{*}{ Motivational Model } & extrinsic motivation \\
\hline & intrinsic motivation \\
\hline \multirow{3}{*}{$\begin{array}{c}\text { Theory of Planned } \\
\text { Behavior }\end{array}$} & Attitude towards act or Behavior \\
\hline & Subjective Norm \\
\hline & Perceived \\
\hline \multirow{4}{*}{$\begin{array}{c}\text { Combined TAM and } \\
\text { TPB }\end{array}$} & Attitude Toward Behavior \\
\hline & Subjective Norm \\
\hline & Perceived Behavioral Control \\
\hline & Perceived Usefulness \\
\hline \multirow{3}{*}{$\begin{array}{c}\text { Model of PC } \\
\text { Utilization }\end{array}$} & Affect Towards Use \\
\hline & Social Factors \\
\hline & Facilitating Conditions \\
\hline \multirow{2}{*}{$\begin{array}{c}\text { Innovation } \\
\text { Diffusion Theory }\end{array}$} & Voluntariness of Use \\
\hline & Results Demonstrability \\
\hline \multirow{5}{*}{$\begin{array}{l}\text { Social Cognitive } \\
\text { Theory }\end{array}$} & Expectations Performance \\
\hline & Expectations Personal \\
\hline & Self-efficacy \\
\hline & Anxiety \\
\hline & Affect \\
\hline
\end{tabular}

Four independent constructs consisted of performance expectancy, effort expectancy, social influence, and facilitating conditions were confirmed. Performance expectancy was defined as "the degree to which an individual believes that using the system will help him or her to attain gains in job performance" and was affected by perceived usefulness, extrinsic motivation, and relative advantage. Effort expectancy was defined as "the degree of ease associated with the use of the system" and was affected by three items namely, perceived ease of use, complexity, and ease of use. Social influence was defined as "the degree to which an individual perceives that important others believe he or she should use the new system" and affected by subjective norm, social factors, and image. Finally, facilitating conditions were defined as "the degree to which an individual believes that an organizational and technical infrastructure exists to support use of the system" and affected by perceived behavioral control, facilitating conditions, and compatibility. Each of these measures is operationalized to include aspects of the technological and organizational environment that are designed to remove barriers to use [4].

It should be mentioned that UTAUT is a unified theory for technology acceptance and use from individual perspective. This theory focused to the features and conditions that influence behavioral intention and use behavior through individuals. UTAUT does NOT focus to success or failure of the IS projects, however influence the success.Table 1 summarizes the models and theories of individual acceptance.

\section{IS MODELS, FRAMEWORK, AND THEORY COMPARISON}

In the previous studies, the relationship between service quality and user satisfaction (quality of satisfaction) besides of the other quality (information quality, system quality) was tested by some researchers [40-43], and the others focused on the effect of quality of a single construct to the other construct's quality [43], while comprehensive model test was ignored among previous investigations.

A crucial issue that has been neglected to consider in the IS models is roles of user in IS success measurement in organizations which was observed by Stacie Petter et al. [2]. The authors think that, this issue was discussed by Venkatesh et al. [4] in the UTAUT theory from different perspective. They claimed that perception is different from person to person [3, 5] which is related to quality of users characteristics and capabilities such as IT capability [1], KM capability [1], education [4], experience [4], motivation [44]. While, Venkatesh et al. [4] investigated on the roles of user as a series of key moderators such as age, gander, experience, and voluntariness, users' role considered as user satisfaction and dissatisfaction in DeLone and McLean IS success model. Gable et al. [15] measured the success of information system by measuring impact of the system on individual and organization as same as D\&M IS success model. They have also measured quality of information and system. However, role of information system quality and its impact has been investigated, the role of user in terms of impact on the information system's success has been overlooked in the ISImpact measurement model as well as Shang and Seddon [25] which did not consider in the ES benefits framework.

Moreover, the authors concluded that beside of system quality, service quality and information quality, user quality affect usage quality and satisfaction quality and UTAUT key moderators will moderate the influences of aforementioned independent qualities on the dependent qualities in an organization especially in health context organizations and accordingly affect the success rate of IS implementation. Table 2 compares and shows the neglected issue in the DeLone and McLean IS success model, IS-impact measurement model, ES benefits framework, and UTAUT. 
Table 2: IS models, framework, and theory comparison

\begin{tabular}{|c|c|c|c|c|}
\hline $\begin{array}{l}\text { Covered Dimension } \\
\text { and issues }\end{array}$ & $\begin{array}{c}\text { D\&M IS success } \\
\text { model }\end{array}$ & $\begin{array}{c}\text { IS-impact measurement } \\
\text { model }\end{array}$ & $\begin{array}{l}\text { ES benefits } \\
\text { framework }\end{array}$ & UTAUT \\
\hline Organization & Net Benefits & Organizational impact & $\begin{array}{c}\text { Strategic benefits, } \\
\text { IT infrastructure } \\
\text { benefits, } \\
\text { Organizational } \\
\text { benefits }\end{array}$ & \multirow[t]{2}{*}{ NOT covered } \\
\hline Information System & $\begin{array}{l}\text { Information, System, } \\
\text { Service, Information }\end{array}$ & $\begin{array}{l}\text { Information qualityand } \\
\text { System quality }\end{array}$ & Operational benefits & \\
\hline User & $\begin{array}{l}\text { Use and user } \\
\text { satisfaction }\end{array}$ & Individual impact & Managerial benefits & \multirow{2}{*}{$\begin{array}{c}\text { Facilitating conditions, } \\
\text { Effort expectancy, } \\
\text { Performance } \\
\text { expectancy, } \\
\text { Social influence,Age, } \\
\text { gender, experience, } \\
\text { Voluntariness }\end{array}$} \\
\hline Neglected issues & \multicolumn{3}{|c|}{$\begin{array}{l}\text { The influence of User's gender, age, experience, education, and User's } \\
\text { capabilities on the success of information system }\end{array}$} & \\
\hline
\end{tabular}

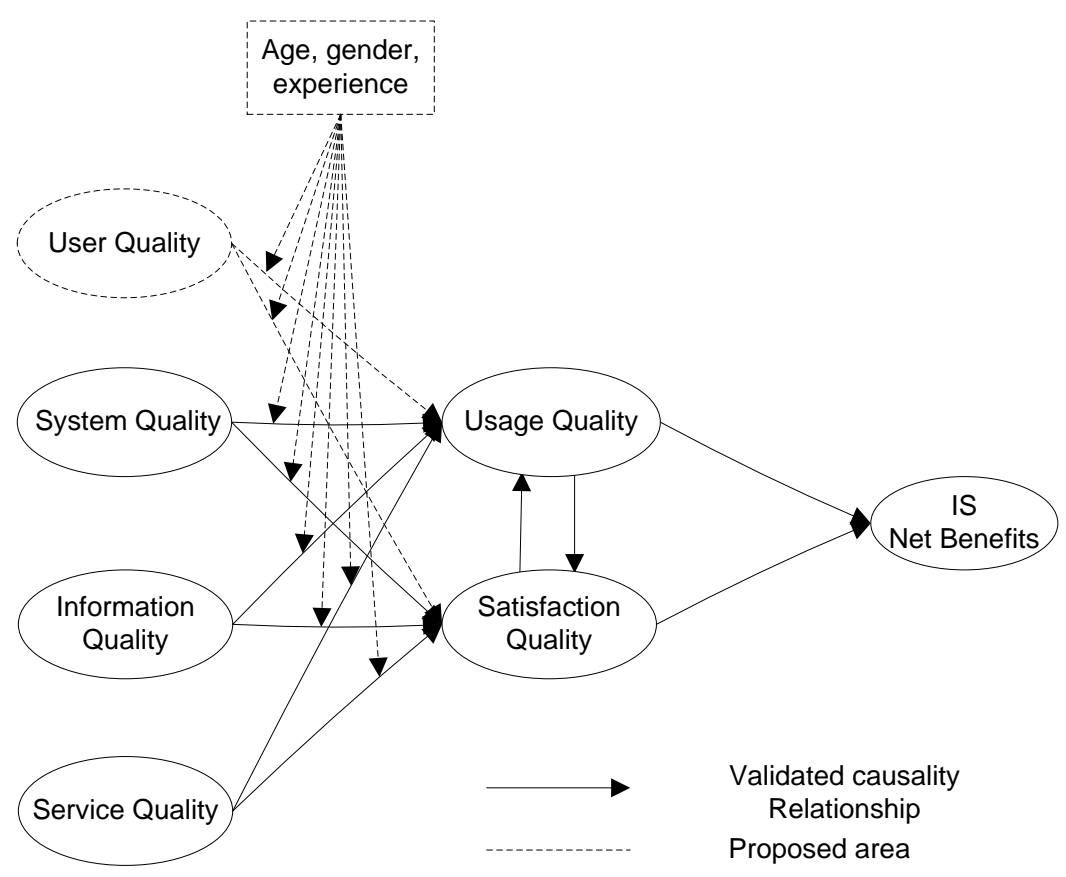

Fig 6: Proposed IS success measurement model

Fig 6 shows the proposed IS Success Measurement Model. IS success measurement model has developed in two main parts. First part is independent variables which consist of user quality, system quality, service quality, and information quality. These independent variables considered as IS success elements, because, the aforementioned four qualities are contributed in the success of IS and without them success is meaningless. Therefore, the researcher claimed that independent variables influence the success of IS. Second part is dependent variables and consists of usage quality, satisfaction quality, and IS net benefits. Dependent variables help to measure the success of IS. It does mean that by improving the qualities of independent variables, the qualities of usage and satisfaction will be increased and accordingly IS net benefits of organization will arise. Fig7 shows two half of IS success measurement model that were discussed in this section.

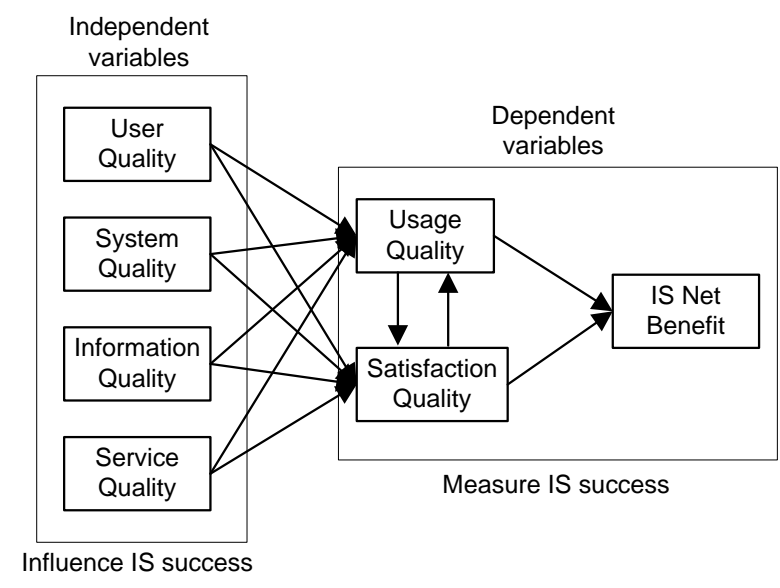

Fig 7: Dependent and independent variables of IS success measurement model 


\section{DISCUSSION}

IS models and framework: have focused to "How success of IS implementation should be measured in an organizations" in various perspectives by different criteria, such as:

DeLoan and McLean IS success model (Fig 2) has focused to quality, usage, satisfaction and accordingly benefit in an organization. Qualities' constructs have presented information's measures, system's measures, and service's measures. Usage construct has measured intention of end user of IS applications to use of the system, while user satisfaction construct has measured satisfaction which has increased or decreased by information system. Finally, benefit construct has measured the IS's impacts and IS's benefits to individuals, groups and organization [18]. However this model has considered the dimensions, the influence of user's role to success of IS implementation has been ignored.

IS-impact measurement model (Fig 4) has considered the success of an IS in two halves; impact half consist of individual and organizational impacts, while quality half consist of information quality and system quality. Gable et al. (2008) measured the success of information system by measuring impact of the system on individual and organization as same as D\&M IS success model. They have also measured quality of information and system as other set of success. However, roles of quality and impact have been considered, the role of user in terms of impact to the information system's success has been overlooked.

Enterprise system benefits framework focused to measure the success of an IS in enterprise information system via measuring five different benefit dimensions consist of operational, managerial, strategic, IT infrastructure, and organizational. Shang and Seddon (2002) measured the increased benefits in aforementioned perspectives by using of IS. However, they measured the information system' success via five benefit's dimension, as same as IS-impact measurement model, the role of user in terms of impact to the information system's success has been not considered.

UTAUT: Venkatesh et al. (2003) at the end of an investigation confirmed that four critical dimension of individual perception affect behavioral intention and use behavioral. They had explored previous theories such as theory of reasoned action, technology acceptance model, Motivational Model (MM), theory of planned behavior, Model of PC Utilization (MPCU), Innovation Diffusion Theory (IDT), and Social Cognitive Theory (SCT) and conclude UTAUT [4]. They have also confirmed that gender, age, experience, and voluntariness moderate the intention behavioral and use behavioral. UTAUT focused to the individual perceptions as a critical role of user in accept and use of information system, while quality of the information system is ignored.

\section{CONCLUSION}

In aforementioned IS models, framework, and theory, distinguished aspects of IS success considered by DeLone and McLean (1992, 2003), Shang and Seddon (2002), and Gable et al. (2008)the role of user (influence of user features and user's capabilities) on the success of information was overlooked, while Venkatesh et al. (2003) investigated the critical role of user and individual perceptions on the accept and use of technology. Finally, by current comparison the authors cleared this reality about neglected role of user in IS success measurements in the IS models and framework.Fig 6 proposed for future study to investigate the role of user in organizations.

\section{REFERENCES}

[1] Shin-Yuan Hung, Wei-Hsi Hung, Chia-An Tsai, and S.C. Jiang, "Critical factors of hospital adoption on CRM system: Organizational and information system perspectives," Decision Suport System, 2010.

[2] Stacie Petter, William DeLone, and E. R. McLean, "The Past, Present, and Future of "IS Success" " Journal of the Association for Information Systems vol. 13, pp. 341362, 2012.

[3] F. Davis, "Perceived usefulness, perceived ease of use, and user acceptance of information technology.," MIS Quarterly vol. 13, pp. 318-346, 1989.

[4] Venkatesh, M. Morris, G. Davis, and F. Davis, "User acceptance of information technology: toward a unified view," MIS Quarterly, vol. 27, pp. 425-478, 2003.

[5] Viswanath Venkatesh and H. Bala, "Technology Acceptance Model 3 and a Research Agenda on Interventions," Decision Sciences vol. 39, pp. 274-315, 2008.

[6] Hossein Monem, Ab Razak Che Hussin, Roxana Sharifian, and H. Shaterzadeh, "CRM Software Implementation Factors in Hospital (Software \& Patient Perspectives )," in 5th Malaysian Software Engineering Conference (MySEC), Malaysia, 2011.

[7] K. A. Richards and E. Jones, "Customer relationship management: Finding value drivers," Industrial Marketing Management, vol. 37, p. 120-130., 2008.

[8] J. H. F. Chen and E. T. G. Wang, "Internalization in technology innovation: A case of CRM adoption.," in 39th Hawaii International Conference on System Sciences, Hawaii, USA., 2006.

[9] B. Heinrich, "Transforming strategic goals of CRM into process goals and activities," Business Process Management Journal, vol. 11, p. 709-723, 2005.

[10] A. R. Zablah, D. N. Bellenger, and W. J. Johnston, "An evaluation of divergent perspectives on customer relationship management: Towards a common understanding of an emerging phenomenon.," Industrial Marketing Management, vol. 33, p. 475-489, 2004.

[11] Hossein Monem, Ab Razak che hussin, and N. Behboodian, "Organizational Perspective of CRM Implementation Factors in Hospital " in Second International Conference on Information System (ICRIIS 2011), Malaysia, Kuala Lumur, 2011.

[12] Sarmad Alshawi, Farouk Missi, and Z. Irani, "Organizational, technial and data quality factors in CRM adoption - SME perspective," ELSEVIER, 2011.

[13]Leon A. Kappelman and E. R. McLean, "Promoting Information System Success: The perspective Roles of user prticipation and user involvement.," Journal of information technology management, vol. 3, 1992.

[14]William H. DeLone and E. R. McLean, "Information Systems Success: The Quest for the Dependent Variable "Information Systems Research, vol. 3, 1992.

[15]Guy G. Gable, Darshana Sedera, and T. Chan, "Reconceptualizaing Information System Success: the ISImpact Measurment Model," Journal of the Association for Information System, vol. 9, pp. 377-408, 2008.

[16]Myers BL, Kappelman LA, and P. VRA., "Comprehensive model for assessing the quality and 
productivity of the information systems function: toward a contingency theory for information systems assessment. ," Information Resources Management Journal, vol. 10, pp. 6-25, 1997.

[17] N. Golafshani, "Understanding Reliability and Validity in Qualitative Research," The Qualitative Report, vol. 8, pp. 597-607 2003

[18] William H. DeLone and E. R. McLean, "The DeLone and McLean Model of Information Systems Success: A TenYear Update," Journal of Management Information Systems / Spring 2003, vol. 19, pp. 9-30, 2003.

[19] Fishbein M and Ajzen I, "Belief, Attitude, Intention and Behavior: An Introduction to Theory and Research," Addison-Wesley, 1975.

[20] Stacie Petter, William DeLone, and E. McLean, "Measuring information systems success: models, dimensions, measures, and interrelationships," European Journal of Information Systems, vol. 17, pp. 236-263, 2008.

[21] Darshana Sedera and W. Wang, "Towards a CRM and SCM Benefits Measurement Model," in ICIS 2009 Proceedings, Association for Information Systems, 2009, p. 85.

[22] livari J, "An empirical test of DeLone-McLean model of information systems success," The DATA BASE for Advances in Information Systems, vol. 36, pp. 8-27, 2005.

[23] M. B. Miles and A. M. Huberman, Qualitative Data Analysis: an Expanded Sourcebook. Thousand Oaks, Calif: Sage Publication, 1994.

[24] Torkzadeh G and D. WJ, "The development of a tool for measuring the perceived impact of information technology on work," Omega, vol. 27, pp. 327-339, 1999.

[25] Shari Shang and P. B. Seddon, "Assessing and managing the benefits of enterprise systems: the business manager's perspective," Information Systems Journal vol. 12, pp. 271-299, 2002.

[26] Pitt LF, Watson RT, and K. CB., "Service quality: a measure of information systems effectiveness," MIS Quarterly vol. 19, pp. 173-187, 1995.

[27] Seddon $P$ and Kiew MY, "A partial test and development of DeLone and McLean's model of IS success," Australian Journal of Information Systems vol. 4, pp. 90- 109, 1996.

[28] Zhu K and K. KL., "Post-adoption variations in usage and value of e-business by organizations: cross-country evidence from the retail industry.," Information Systems Research vol. 16, pp. 61-84, 2005.

[29] DeLone WH and M. ER, "Measuring e-commerce success: applying the DeLone \& McLean information systems success model.," International Journal of Electronic Commerce, vol. 9, pp. 31-47, 2004.

[30] MOLLA A and LICKER PS " E-commerce systems success: an attempt to extend and respecify the DeLone and McLean model of IS success.," Journal of Electronic Commerce Research, vol. 2, pp. 131-141, 2001.

[31]Jennex ME and O. L., "Organizational memory/knowledge effects on productivity: a longitudinal study," in Thirty-Fifth Hawaii International Conference on System Sciences, Big Island, Hawaii, USA, 2002, p. 109.

[32] Kulkarni UR, Ravindran S, and F. R., "A knowledge management success model: theoretical development and empirical validation," Journal of Management Information Systems, vol. 23, pp. 309-347., 2006.

[33] Wu J-H and W. Y-M., "Measuring KMS success: a respecification of the DeLone and McLean model," Information \& Management, vol. 43, pp. 728-739, 2006.

[34] Ballantine J, Bonner M, Levy M, Martin Aim, and P. PL., " The 3-D model of information systems success: the search for the dependent variable continues. ," Information Resources Management Journal vol. 9, pp. 5-14, 1996.

[35] Seddon P, Staples S, Patanyakuni R, and Bowtell M, "Dimensions of information systems success," Communications of the Association for Information Systems Research, vol. 2, pp. 2-39, 1999.

[36] S. Gregor, "The nature of theory in information systems," Mis Quarterly, vol. 30, pp. 611-642, 2006.

[37] I. Ajzen, From Intentions to Actions: A Theory of Planned Behavior. Action Control - From Cognition to Behavior J. Kuhl, Beckmann, J. Berlin u. a, 1985.

[38] I. Ajzen, "The Theory of Planned Behavior," Organizational Behavior and Human Decision Processes vol. 50, pp. 179-211, 1991.

[39] F. D. Davis, "A Technology Acceptance Model for Empirically Testing New End-User Information Systems: Theory and Results," PhD, Sloan School of Management Massachusetts Institute of Technology, Cambridge, MA, 1986.

[40] N. J. Blunch, Introduction to Structural Equation Modeling using SPSS and AMOS vol. 1. London: SAGE Publications Ltd, 2008.

[41] S. B. MacKenzie, P. M. Podsakoff, and C. B. Jarvis, "The problem of measurement model misspecification in behavioral and organizational research and some recommended solutions," Journal of Applied Psychology vol. 90, pp. 710-730, 2005.

[42] George A.Morgan, Nancy L. Leech, Gene W. Gloeckner, and K. C. Barret, SPSS for Introductory Statistics: Use and Interpretation. United States of America: Lawrence Erlbaum Associates 2007.

[43] Burton-Jones and D. W. Straub, "Reconceptualizing System Usage: An Approach and Empirical Test," Information Systems Research, vol. 17, pp. 228-246, 2006.

[44]Luis E. Mendoza, Alejandro Marius, María Pérez, and A. C. Grimán., "Critical success factors for a customer relationship management strategy," Information and Software Technology, pp. 913-945, 2006 